\title{
BIOPREPARATIONS FOR THE PRODUCTION OF ENVIRONMENTALLY SAFE FOOD - Part I
}

\author{
Tatiana Nugmanova
}

\begin{abstract}
Russian biopreparations cover almost all aspects of the problem of growing plants. The history of development and implementation of industrial large-scale production of biopreparations in Russia goes back more than 40 years. Biopreparations have a purposeful action and are divided into the following main types: bioinsecticides, biofungicides, biofertilizers, immunomodulators and regulators of plant growth and development, as well as landfertilizing biopreparations. The variety of Russian biopreparations can fully ensure the implementation of the potential varietal properties of agricultural plants, minimize damage from adverse weather conditions, reduce the cost of chemicals, restore soil humus and obtain environmentally friendly food.
\end{abstract}

Keywords: biotechnology, biopreparations, plants, ecology, biofungicides, growth biostimulators, bioinsecticides, industrial production.

\section{INTRODUCTION}

Providing the population with ecologically safe food products is a national task for any country. This is connected with the unprecedented pollution of soil, air and drinking water with chemicals and wastes from enterprises.

New terms appeared in the world nowadays: "organic farming, organic food products". They mean production of products without use of chemical pesticides.

Vegetables and cereals are among main food products. The volume growth of the vegetables produced in Russia is $12 \%$ in two years [1]. Consumption of vegetables and fruits is a prevention of such terrible diseases as cancer, asthma, heart attack. It reduces the risk of heart attack by $43 \%$, lung cancer by $50 \%$, liver cancer - up to $50 \%$, uterus cancer - up to $30 \%$.

Potatoes and grains have the highest volume of production among agricultural products in Russia. Previously, each introduced $\mathrm{kg}$ of mineral fertilizers gave $28 \mathrm{~kg}$ of yield increase, currently it gives only 5 $\mathrm{kg}$. The effectiveness has been significantly reduced by suppressing the beneficial microflora of soil, resulting in its obvious degradation. For example, the straw that remains in the fields doesn't naturally decompose. At the same time, it is shown that the use of microorganisms for soil and plant cultivation can give from 50 to $300 \mathrm{~kg}$ of nitrogen per hectare, which is equivalent to 1 ton of mineral fertilizers.

Therefore, it is extremely important to use the results of innovative agrotechnological development that can solve such problems as increasing the productivity of agricultural plants, improving the quality and safety of products, as well as preserving and restoring of soil fertility.

What can biotechnologists offer right now to help the agriculture? Years of scientific and industrial experience in the sphere of industrial development of biopreparations for agriculture can assure that complex method of using the biopreparations, specifically the
System of biofertilizers, biofungicides and bioinsecticides, fertilizing biopreparations, biofertilizers and immunomodulators, is capable to give the necessary protection, increase drought resistance, provide a yield increase up to $28 \%$, obtain a high-quality crop with minimal chemistry use, reduce the maturation period by $1.5-2$ weeks, increase the quality indicators: starch, vitamins, gluten, oil, dry substances, organic acids, energy value and other indicators. As the result, it can give the consumer an environmentally friendly high-quality product.

\section{MATERIALS AND METHODS}

The following biopreparations were used during the study:

BICOL - bioinsecticide, produced according to the unified author's technology based on the polycomponent nutrient medium (PCM) and bacteria Bac. Thuringiensis ssp. Thuringiensis strain 98 in apparatus $\mathrm{V}=63 \mathrm{~m}^{3}$. This biopharmaceutical is made in the form of a dry wettable powder with a viable spore titer of 609 spores/g and the biological activity of $\mathrm{LC}_{50}=10.1 * 10^{6} \mathrm{spores} / \mathrm{ml}$ for larvae of the second-generation gypsy moth [2]. BICOL effectiveness was determined in the field on various insects using standard and ultra-small-volume sprayers in accordance with generally accepted conditions for the use of biopreparations with a flow rate 0.28 to $1.2 \mathrm{~kg} / \mathrm{ha}$.

LUTAN - complex biofungicide, also produced according to the author's technology based on several strains of Trichoderma fungi. It is a broad-spectrum biofungicide for different phytopathogens, and it contains 3 to 5 different active components. LUTAN was produced in apparatus $\mathrm{V}=1.5 \mathrm{~m}^{3}$ and $10 \mathrm{~L}$ in the form of a liquid suspension concentrate. Biofungicide was used against various diseases of the following plants: apple, cabbage, beet, cucumber, tomato, grapes, and flowers in a dose of 0.5 to 1.5 liters per 1 hectare by spraying with a working suspension. The efficiency analysis was carried out by standard methods. 
NIKFAN - liquid biofertilizer, also produced according to the author's technology based on endophytic fungi, in a form of a liquid concentrate in apparatus $\mathrm{V}=10 \mathrm{~L}$ [2]. This preparation contained active metabolites of the culture-producer: auxins and cytokinins phytohormones, precursors of phytohormones, active microelements, humic and fulvic acids, potassium, silicon and components of the commodity form: stabilizer, antibacterial component, perfume. NIKFAN was used in the form of a working suspension with a dose of 1-2 $\mathrm{ml}$ per 1 hectare, as well as a concentrated working suspension with a dose of 0.4 liters per 1 hectare as a sheet dressing and $0.8 \%$ suspension for seed treatment before sowing.

The efficiency of biopreparations was verified according to the following indicators: the number of fruits, the weight of the fruit, the maturation period, the color intensity of the leaves, the content in the leaves of chlorophyll, and also according to the concentration of vitamins, energy value and other indicators in the case of fodder corn.

\section{RESULTS AND DISCUSSION}

The main effects of implementation of innovative agrotechnological developments:

- Increase of productivity of agricultural plants;

- Improving of the quality of products;

- Improving of safety items;

- Conservation and restoration of soil fertility;

- Production of environmentally safe food.

At the same time, the content of toxins, the infection with phytopathogens and harmful insects are minimized. The above effects can be achieved only through the application of a systematic approach consisting of the use of biopreparations: bioinsecticides, biofungicides and biofertilizers. This system should also include the right crop rotation, high-quality seeds, use of siderate-plants, use of specific biologics: nitrogen fixers and phosphomobilizing preparations, as well as special means - traps from harmful insects. All of the above components of the System provide the required effects, revitalize the soil microflora and restore soil humus.

The use of biopreparations makes it possible to use food in 3-5 days after treatment. It is proved that biological products not only don't affect the taste, color and nutritional value of products, but also increase the content of vitamins and mineral components.

For a long period of industrial production of CPP (crop protection product) biopreparations (from 1972, when maximum productivity of Russian factories reached 11,000 tons of CPP biopreparations in the form of dry wettable powders per year in 1982, to the present day) the high efficacy of biologics and their ecological safety was proved.
The BICOL bioinsecticide contains a sporecrystalline complex as an active principle and an exotoxin, produced by bacterial cells. The main difference between bioinsecticides and chemicals is that they are developed on the basis of microorganisms taken from nature, they have high selectivity of action and they are harmless to humans, animals and useful insects. The effectiveness of protection reaches $80-97 \%$. For example, BICOL protects beets, carrots, cabbage and other vegetables from a complex of leaf-eating caterpillars: celery looper, white butterfly, meadow moth, with a concentration of $4-5 \mathrm{~g}$ of the preparation per 1 liter. To protect apples, pears, cherries, plums against the apple moth caterpillars, leafworm, moth, hawthorn, American white butterfly, silkworm and other insects, the biopreparation is used in a concentration of $5-7 \mathrm{~g} / \mathrm{L}$. BICOL is effective against leaf rollers caterpillars, melonworm, moth, leaf gall midges, spider mites at a concentration of $8 \mathrm{~g}$ per liter. It is also effective against pests of medicinal herbs. BICOL is a splendid protection of cucumbers, flowers and peppers in greenhouses from spider mite [2].

Biofungicides are able to suppress fungal and bacterial infections and are mainly produced from microorganisms derived from natural objects, often these are soil inhabitants. Among the most common producers of biofungicides are fungi of the genus Trichoderma, bacteria Bac. Subtilis, Pseudomonas, Azomonas agilis, Azotobacter. Biofungicides made from bacterial strains of Bac.subtilis are well known as a good source of antibiotics and enzymes that also have high efficiency. Some preparations are made from Pseudomonas aureofaciens and fluorescens, which are known for a long time as producers of antibiotics and biologically active substances, capable to inhibit phytopathogens and to stimulate plant growth. Pseudomonas, in contrast to bacilli, have an even faster growth rate and, as a rule, can accumulate up to $10^{12}$ cells per $\mathrm{ml}$ in the culture liquid after 10-15 hours of growth. Fungal preparations are usually based on the use of saprophytic fungi of the genus Trichoderma. Trichoderma now has 88 different species and is characterized by an exceptionally rich composition of metabolites. Fungi of the genus trichoderma are natural antagonists living in the soil. Biologically active compounds of trichoderma include a variety of antibiotics: gliotoxin, viridine, trichoviridine, dermatin, cyclosporine, trichopolin A and B, volatiles: carbon dioxide, ethanol, volatile antibiotics, enzymes: cellulolytic enzymes, chitinase, helicase, amylase, catalase, pentonase. In addition to these substances, trichoderma secretes hormone-like substances - growth stimulators. Biopreparations have a complex effect on the plant: protective properties, stimulating properties, as well as destructors of stubble residues. 
They effectively protect seeds, plants and tubers from rot caused by various phytopathogenic fungi: Fusarium, Alternaria, Rhoma, Ascochuta, Verticillium, Rhizocini, Scleratinia, Botrytis, Septoria etc., which can cause the formation of gray and white rot, root rot, powdery mildew, late blight, mildew, oidium, scab and other plant diseases during growth in the field, as well as during long-term storage of products. The use of LUTAN biofungicide in our work has shown that it has very high fungicidal activity and not only protects plants from a wide range of fungal infections, but also increases the yield of cucumbers by $0.5-3.0 \mathrm{~kg} / \mathrm{m}^{2}$, cereals by $15-30 \%$, cabbage and other vegetables by $40 \%$ [3].

Biofungicides based on Trichoderma, are able to work also at low temperatures, effectively protecting vegetables during their long-term storage at $+2+3^{\circ} \mathrm{C}$.

The most important direction is the production of biofertilizers with evident signs of growth stimulant and immunomodulator. An example of such biopharmaceutical is Biofertilizer NIKFAN.

This biopharmaceutical, produced on the basis of endo- and ectophytic fungi, living as a natural microflora in living plants, is a producer of a highly effective biopharmaceutical with a complex of various properties useful for plants [3]. It is the source of a whole complex of biologically active substances: vitamins, microelements, enzymes, amino acids, natural phytohormones: auxins, cytokinins, potassium, silicon, humic and fulvic acids. This is due to its polyfunctionality.

Main effects:

- Increase in root formation;

- Increased germination of seeds and tubers;
- Intensification of nitrogen fixation, photosynthesis;

- Increase of plant immunity, frost resistance and drought resistance;

- Increased resistance to fungal diseases;

- Improving the growth of rootstock and graft;

- Increase in the consumer properties of plants (increase of the gluten content of grain, technological properties of fiber, sugar content);

- Increase in the growth of shoots, bushiness, decrease in the lag in the ovaries.

High efficiency of NIKFAN on various plants is shown: wheat, barley, oats, corn, rapeseed, soy, rice, vegetables, fruit trees, grapes, berry crops, ornamental plants in different countries: Russia, Colombia, India, China, Bulgaria, Zambia, Lithuania.

One of the main effects is a significant increase in root formation, which, together with other effects, leads to an increase in yields and a shortening of maturation periods by 1.5 to 2 weeks, as well as to an increase in plant resistance to adverse weather conditions, significant (by 20-60\%) increase in yield, acceleration of the growth and development of plants, improvement of the quality characteristics of plants: gluten, starch, vitamins, microelements. Tests in greenhouses showed an increase in the yield of cucumber by $38-51 \%[4,5,6]$. Fodder corn showed a significant increase in sugar by $36 \%$, protein by $26 \%$, and carotene by 2.7 times (Table 1 ). The study of the content of selenium in the processed beet showed (Table 2) a significant increase in this most important index. The results of implementation of the NIKFAN biopreparation for cereals are presented in Table 3.

Table 1. Nutrient content of green mass of maize after application of fertilizer NIKFAN

\begin{tabular}{|c|c|c|c|c|}
\hline \multirow[b]{2}{*}{ № } & \multirow{2}{*}{ Items } & \multicolumn{3}{|c|}{ Experiment versions } \\
\hline & & $\begin{array}{c}\text { Control } \\
\text { (without treatment) }\end{array}$ & $\begin{array}{l}1 \mathrm{ml} \text { of NIKFAN } \\
\text { (seed treatment) }\end{array}$ & Increase, $\%$ \\
\hline 1 & $\begin{array}{l}\text { Green mass, } \mathrm{kg} \\
\% \text { rel. to the control }\end{array}$ & $\begin{array}{c}1422 \\
-\end{array}$ & 1755 & 123 \\
\hline 2 & $\begin{array}{l}\text { Dry matter, kg } \\
\quad \% \text { rel. to the control }\end{array}$ & $\begin{array}{c}262 \\
-\end{array}$ & 357 & 136 \\
\hline 3 & $\begin{array}{l}\text { Crude protein, } \mathrm{kg} \\
\% \text { rel. to the control }\end{array}$ & $\begin{array}{c}28,5 \\
-\end{array}$ & 36,0 & 126 \\
\hline 4 & $\begin{array}{l}\text { Crude fat, } \mathrm{kg} \\
\quad \% \text { rel. to the control }\end{array}$ & $\begin{array}{c}5,48 \\
-\end{array}$ & 7,58 & 138 \\
\hline 5 & $\begin{array}{l}\text { Raw fiber, } \mathrm{kg} \\
\quad \% \text { rel. to the control }\end{array}$ & $\begin{array}{c}55,7 \\
-\end{array}$ & 78,2 & 140 \\
\hline 6 & $\begin{array}{l}\text { Nitrogen-free extractive } \\
\text { substances, kg } \\
\quad \% \text { rel. to the control: } \\
\text { including starch } \mathrm{kg} \\
\% \text { rel. to the control } \\
\text { Sugar, } \mathrm{kg} \\
\quad \% \text { rel. to the control }\end{array}$ & $\begin{array}{c}144 \\
- \\
19,6 \\
- \\
49,7 \\
-\end{array}$ & $\begin{array}{l}27,7 \\
67,9\end{array}$ & $\begin{array}{l}141 \\
136\end{array}$ \\
\hline 7 & $\begin{array}{l}\text { B-carotene, } \mathrm{g} \\
\% \text { to the control }\end{array}$ & $\begin{array}{c}3,79 \\
-\end{array}$ & 10,4 & 275 \\
\hline 8 & Gross energy, $\mathrm{MJ} / \mathrm{kg}$ & 3,18 & 3,54 & 11,3 \\
\hline
\end{tabular}


Table 2. Influence of the biopharmaceutical NIKFAN on the intensity of beet growth (research in All-Russian Research Institute of Selection and Seed Vegetable Crops)

\begin{tabular}{|l|c|c|}
\hline \multicolumn{1}{|c|}{ Item } & Study & Control \\
\hline Average weight of plant root, $\mathrm{g}$ & 0.93 & 0.20 \\
\hline Average weight of leaves, $\mathrm{g}$ & 3.0 & 0.93 \\
\hline Plant leaf area, $\mathrm{mm}^{2}$ & 57.6 & 41.7 \\
\hline Selenium content, $\mu \mathrm{g} / \mathrm{kg}:$ & & not determined \\
In root crops & 460 & 196 \\
In leaves & 216 & \\
\hline
\end{tabular}

Table 3. Results of NIKFAN testing on cereals, Krasnodar Territory

\begin{tabular}{|c|c|c|c|}
\hline Grain crops & Area, hectares & Application rate, $\mathrm{ml} / \mathrm{ha}$ & $\begin{array}{l}\text { Productivity, } \\
\text { Centner/ha }\end{array}$ \\
\hline \multicolumn{4}{|c|}{ WINTER WHEAT } \\
\hline \multirow[t]{2}{*}{$\begin{array}{l}\text { Winter wheat, "Vita", LLC } \\
\text { Agricultural company } \\
\text { "Kolos", Kalininsky district }\end{array}$} & 40.0 & $\begin{array}{l}1.5 \mathrm{ml} \text { together with } \\
\text { herbicides } \\
1.0 \mathrm{ml} \text { by terrestrial } \\
\text { method together with } \\
\text { fungicides (aero spraying) }\end{array}$ & $\begin{array}{l}73.7 \\
\text { Addition to the } \\
\text { crop } 18.1 \% \\
\text { Gluten } 26 \%\end{array}$ \\
\hline & 80.0 & Control & 62.4 \\
\hline \multirow{2}{*}{$\begin{array}{l}\text { Winter wheat, } \\
\text { "Pamyat", Agricultural } \\
\text { company "Selhoz-Contract" }\end{array}$} & 25.0 & $\begin{array}{l}1.5 \mathrm{ml} \text { together with } \\
\text { fungicides and } 1.0 \mathrm{ml} \text { by } \\
\text { terrestrial method together } \\
\text { with herbicides }\end{array}$ & $\begin{array}{c}58.9 \\
\text { Addition to the } \\
\text { crop } 31.7 \% \\
\text { Gluten } 25 \% \\
\end{array}$ \\
\hline & 25.0 & Control & 44.7 \\
\hline \multicolumn{4}{|c|}{ WINTER BARLEY } \\
\hline \multirow{2}{*}{$\begin{array}{l}\text { Winter barley, "Kondrat" } \\
\text { Agricultural company } \\
\text { "Kolos" }\end{array}$} & 40.0 & $\begin{array}{l}1.5 \mathrm{ml} \text { together with } \\
\text { herbicides by ground } \\
\text { method }\end{array}$ & $\begin{array}{c}57.7 \\
\text { Addition to the } \\
\text { crop } 5.9 \% \\
\end{array}$ \\
\hline & 100.0 & Control & 54.5 \\
\hline \multicolumn{4}{|c|}{ SUGAR BEET } \\
\hline \multirow{2}{*}{$\begin{array}{l}\text { Sugar beet, } \\
\text { "Atamansha" } \\
\text { Agricultural company } \\
\text { "Kolos", Kalininski district, } \\
2009\end{array}$} & 40 & $1.5 \mathrm{ml}$, by aviation method & $\begin{array}{c}478 \text { Centner/ha, } \\
\text { Addition to the } \\
\text { crop } 11.6 \% \\
\end{array}$ \\
\hline & 68 & Control & 428 Centner/ha \\
\hline \multicolumn{4}{|c|}{ SUNFLOWER } \\
\hline \multirow{2}{*}{$\begin{array}{l}\text { Sunflower, hybrid A-83, } \\
\text { Agricultural company } \\
\text { "Kolos", Kalininski district, } \\
2009\end{array}$} & 40 & $1.5 \mathrm{ml}$, by aviation method & $\begin{array}{c}38.2 \text { Centner/ha } \\
\text { Addition to the } \\
\text { crop } 8.2 \%\end{array}$ \\
\hline & 220 & Control & 35.3 Centner/ha \\
\hline
\end{tabular}


The effectiveness of biopreparations LUTAN and NIKFAN is presented in photos on Fig. 1-6.

\section{The efficiency of biopreparation Lutan}
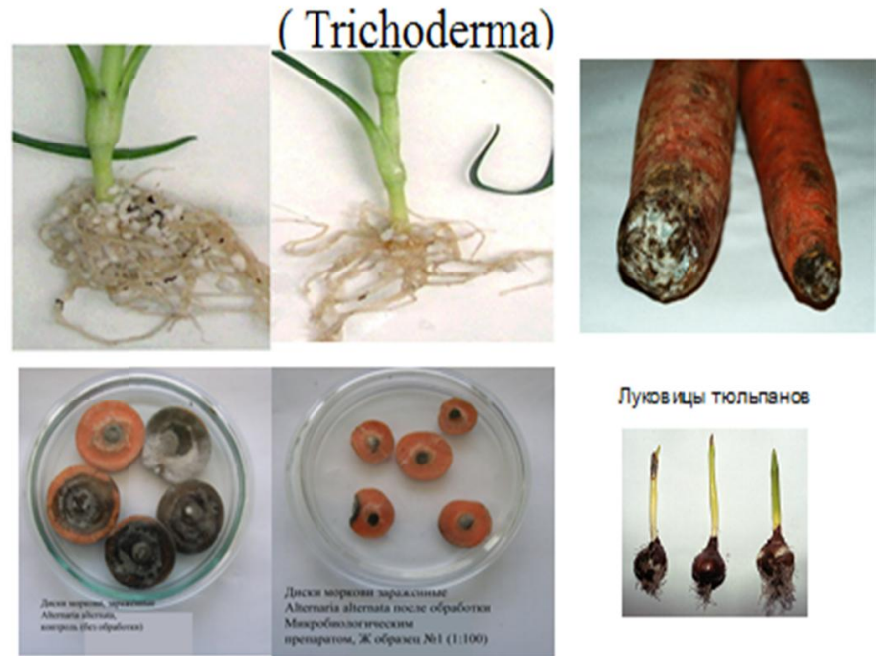

Луковицы тюльпанов

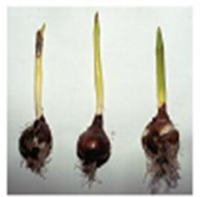

Efficacy of the biofungicide LUTAN

Fig. 1. Efficiency of LUTAN on carrots, bulbs of tulips and lilies

The infestation of Apple trees Venturia

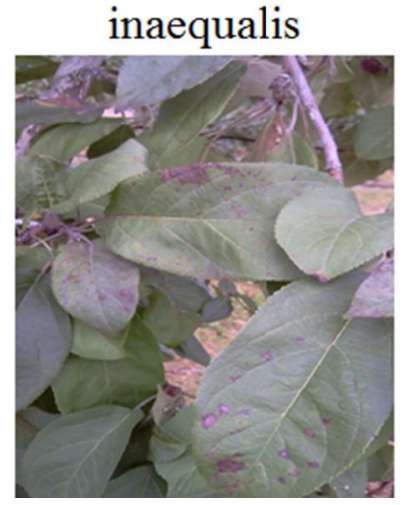

Apple-tree, brown rust

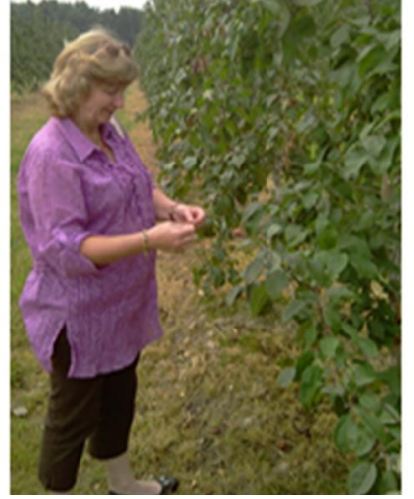

Apple-trees after treatment with biofungicide

Fig. 2. Efficiency of LUTAN on apple trees against scab

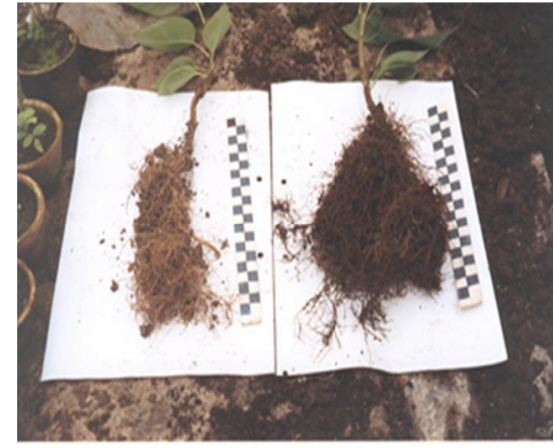

Roots of lilac seedlings Control Experiment

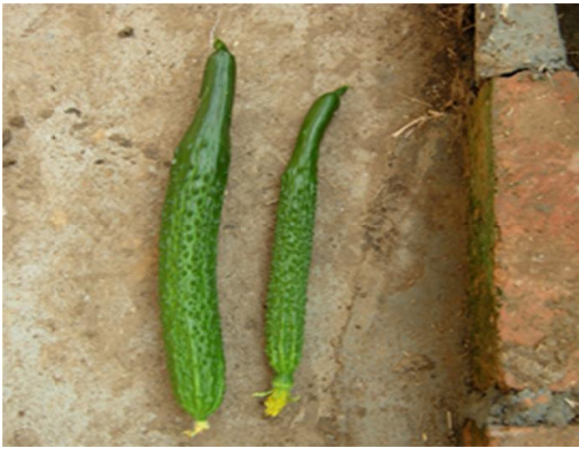

Cucumber fruits, China Experiment Control

Fig. 3. Effectiveness of NIKFAN on lilac and cucumber seedlings 
Saplings of Apple trees, Krasnodar nursery ( age 1 year)

Control

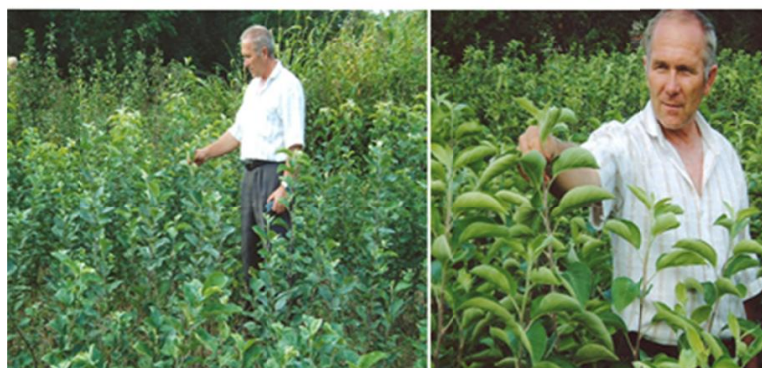

Apple seedlings, Krasnodar nursery, (one-year-olds) Control

Experiment

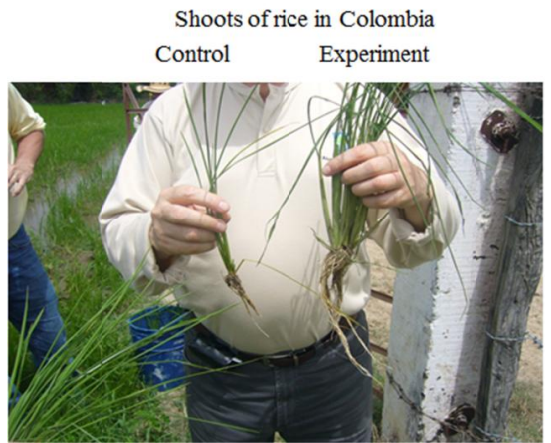

Rice sprouts in Colombia Control Experiment

Fig. 4. Efficiency of NIKFAN on apple and rice seedlings

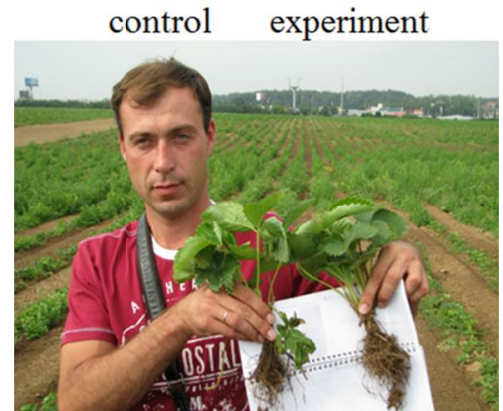

Strawberry, Lenin farm, Moscow Oblast, 2011

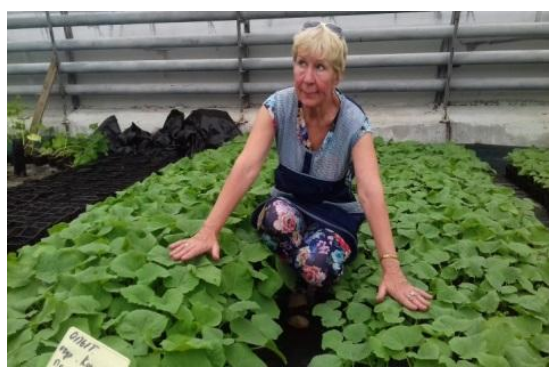

Cucumbers, treatment by NIKFAN

Fig. 5. Effectiveness of NIKFAN on strawberry and cucumber seedlings in the greenhouse

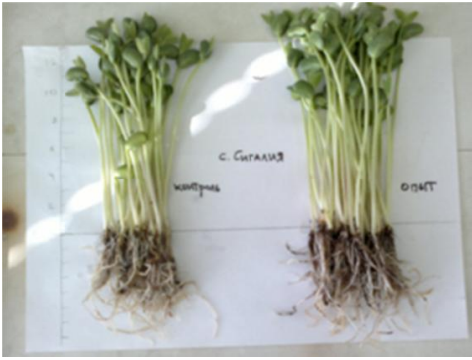

Effectiveness of NIKFAN on soybean cultures in laboratory conditions Control Experiment

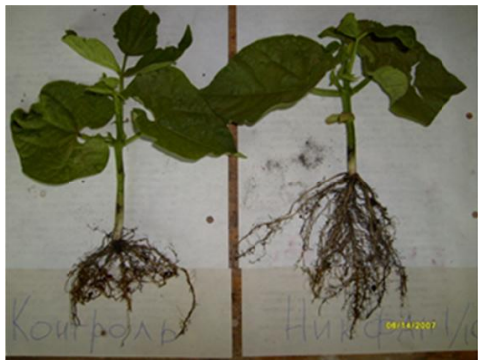

Soya, Ulyanovsk, Agricultural Academy

Control Experiment

Fig. 6. Effectiveness of NIKFAN on soybean underground seedlings and soybean seedlings

\section{CONCLUSION}

It is shown that biological products are the basis of agrotechnology, which presupposes the production of ecologically safe food products. Each of them is able to protect plants from sucking and gnawing insects and phytopathogens, increase immunity, enable the plant to realize its varietal properties. In addition, fruits, root crops, grain reach higher quality and grade. Thus, the content of sugar increases by $2-3 \%$, protein by $5 \%$, fiber by $2 \%$, starch by $10 \%$, gluten by $22 \%$, maturation time decreases by 1.5 weeks, resistance to diseases improves $87 \%$. 


\section{REFERENCES}

1. Nugmanova, T.A., Use of biological products for obtaining environmentally friendly food. Collection of works of the Russian Academy of Natural Sciences, "Unconventional natural resources, innovative technologies and products", No 23, 2016, 103-107.

2. Nugmanova, T.A., Unified Technology of Biological Toxins as the Basis for the Industrial Production of Effective Bacterial Insecticides. Doctor of Technical Sciences Thesis, Moscow, 1992. 389.

3. Nugmanova, T.A., Biopreparations - products of microbiological synthesis for the production of ecologically safe food products: technology, advantages, perspectives, Ecological Aspects of the Life of Man, Animals and Plants, Publishing House "Belgorod"2017,45-76.
4. Chistyakova, L.A., Petra, I.K., Nugmanova, T.A., Grushina, O.A., Imbiya A.M., Nikfan: Protection and Harvesting // Potatoes and vegetables, 2016, No.11, pp. 20-21

5. Chistyakova, L.A., Nugmanova, T.A., Growth regulators on cucumber. Potatoes and vegetables, 2016, No.8, 14.

6. Nugmanova, T.A., Bioinsecticides, biofungicides and biostimulants. Role in vegetable growing and potato growing, Potatoes and vegetables, 2017, No. 6, pp. 2-4.

7. Nugmanova, T.A., Grushina, O.A., Sorokopudov, V.N., The use of biologics for crop production, International scientific journal "Successes of Modern Science", No. 10, Volume 5, 2016, pp. 128-131.

\title{
БИОПРЕПАРАТИ ЗА ПРОИЗВОДСТВО НА ЕКОЛОГИЧНО БЕЗОПАСНИ ХРАНИ - Част I
}

\author{
Татяна Нугманова
}

Резюме: Руските биопрепарати обхващат почти всички аспекти и проблеми свързани с отглеждането на растения. Историята на разработването и внедряването на промишлено мащабно производство на биопрепарати в Русия датира повече от 40 години. Биопрепаратите имат целенасочено действие и са разделени на следните основни типове: биоинсекциди, биофунгициди, биостимулатори, имуномодулатори и регулатори на растежа и развитието на растенията, както и биопрепарати за наторяване на земята. Разнообразието от руски биопрепарати може да осигури напълно реализацията на потенциалните сортови свойства на селскостопанските растения, да сведе до минимум щетите от неблагоприятни климатични условия, да намали разходите за химикали, да възстанови почвения хумус и да получи екологично чиста храна.

Ключови думи: биотехнологии, биопрепарати, растения, екология, биофунгициди, растежни биостимулатори, биоинсектициди, промишлено производство

T.A. Nugmanova, DSc, Professor of Biotechnology, Academician of RANS

Director company "BIOIN-NOVO", Moscow.

e-mail: bioin@yandex.ru 